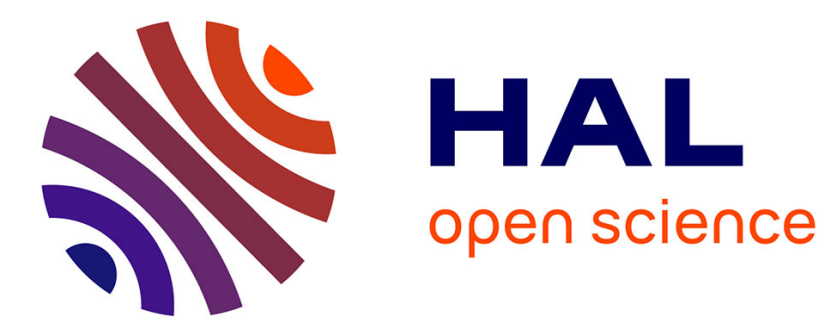

\title{
Characterization of industrial dried whey emulsions at different stages of spray-drying
}

\author{
Emilie Donz, P. Boiron, Jean-Luc Courthaudon
}

\section{To cite this version:}

Emilie Donz, P. Boiron, Jean-Luc Courthaudon. Characterization of industrial dried whey emulsions at different stages of spray-drying. Journal of Food Engineering, 2014, 126, pp.190-7. 10.1016/j.jfoodeng.2013.11.003 . hal-03179492

\section{HAL Id: hal-03179492 \\ https://univ-angers.hal.science/hal-03179492}

Submitted on 24 Mar 2021

HAL is a multi-disciplinary open access archive for the deposit and dissemination of scientific research documents, whether they are published or not. The documents may come from teaching and research institutions in France or abroad, or from public or private research centers.
L'archive ouverte pluridisciplinaire HAL, est destinée au dépôt et à la diffusion de documents scientifiques de niveau recherche, publiés ou non, émanant des établissements d'enseignement et de recherche français ou étrangers, des laboratoires publics ou privés.

\section{()ㅜ) $\Theta$}

Distributed under a Creative Commons Attribution - NoDerivatives| 4.0 International 


\title{
Characterization of industrial dried whey emulsions at different stages of spray-drying
}

\author{
E. Donz ${ }^{\text {a }}$, P. Boiron ${ }^{\text {b }}$ J.-L. Courthaudon ${ }^{\text {a,* }}$ \\ a UMR S-1066, MINT Micro-Nanomédecines Biomimétiques, LUNAM University, Angers, France \\ ${ }^{\mathrm{b}}$ CRITT (Centre Régional d'Innovation et de Transfert de Technologie) Agro-Alimentaire et Biotechnologies La Rochelle, France
}

\section{A R T I C L E I N F O}

\section{Article history:}

Available online 14 November 2013

\section{Keywords:}

Whey emulsion

Spray-drying

Fine

Stability

Powder size

\begin{abstract}
A B S T R A C T
Commercial dried food emulsions, with high fat content (50 g fat $/ 100 \mathrm{~g}$ ), were prepared at plant scale from whey and palm oil. Five powders were analyzed: powder without fines, taken from the bottom of the spray-dryer chamber; fines 1 and fines 2 respectively collected at the bottom of the first and second cyclones, a mix of fines 1 and fines 2 and the final powder, taken during packing. Scanning electronic and optical microscopy showed only spherical particles and also indicated that fines 2 were roughly twice as smaller as other powder particles. Free fat content was significantly higher in fines than in final powder. Reconstituted emulsions ( $10 \mathrm{~g}$ powder/100 g water) were analyzed by laser light scattering. Aggregation and coalescence indexes were very low, except in reconstituted emulsions made with fines 2 . This is consistent with their high free fat content and suggests that this results from processing through the cyclones.
\end{abstract}

(c) 2013 Elsevier Ltd. All rights reserved.

\section{Introduction}

Many food products are dispersed systems of two immiscible phases: water-in-oil (w/o) emulsions such as butter or oil-in-water $(\mathrm{o} / \mathrm{w})$ emulsions such as milk or cream. One phase exists as small dispersed particulates, known as the dispersed phase (Hayati et al., 2007), the other being the continuous phase. Food oil in water emulsions are complex systems that require stabilization of the fat droplets by proteins, small-molecule surfactants (emulsifiers) and, in certain cases, polysaccharides (Dickinson, 2010). Emulsions can undergo different types of instabilities that involve changes with droplet size, such as coalescence and Oswald ripening, or instabilities that involve the spacial rearrangement of the droplets such as flocculation and creaming (Lizarraga et al., 2008). These mechanisms can lead to a destabilization of the system with total phase separation. The presence of an adsorbed protein layer at the surface of droplets is a stabilizing factor through steric and electrostatic mechanisms. Effectiveness of this kind of stabilizing layer depends on how difficult it is to displace it from the interface (Dickinson, 2010).

To increase physical and microbiological stability, and reduce transport and storage costs, liquid emulsions can be transformed into powders by spray-drying (Gharsallaoui et al., 2007; Rattes and Oliveira, 2007; Schuck, 2002). Spray drying is a major process of water removal in milk powder production. The principle is to

\footnotetext{
* Corresponding author. Tel.: +33244688533.

E-mail address: jean-luc.courthaudon@univ-angers.fr (J.-L. Courthaudon).
}

remove water from the o/w emulsion at the lowest temperature and the shortest time possible in order to minimize heat damage toward the milk solids. This is achieved by spraying the emulsion as very fine droplets by a nozzle or a rotary atomizer into hot dry air steam at $180-220^{\circ} \mathrm{C}$ (Gharsallaoui et al., 2007). Drying emulsions can only be successfully achieved if liquid emulsions contained a solid carrier, such as maltodextrins (soluble), or colloidal silica (insoluble) (Christensen et al., 2001a). Indeed, by drying, the aqueous phase is removed, leaving the solid carrier as the bulk matrix able to form the powder particles and protect the oil phase (Christensen et al., 2001b). Milk proteins are widely valued as food ingredients because of their surface-active and colloid-stabilizing properties. Adsorption of milk proteins at the lipid-water interface creates both electrostatic and steric repulsion that protects the particulates against coalescence and thus destabilization of the emulsion (Lizarraga et al., 2008). This stands for most dairy emulsions such as ice cream or dairy foams in which the presence of a thick and negatively charged layer prevents coalescence of lipid droplets (Tomas et al., 1994)). In dried dairy emulsions, the matrix protecting the fat droplets is composed of proteins and carbohydrates such as lactose (Fäldt and Bergenst/aahl, 1996a). Compared to other sugar, lactose exhibits low hydroscopicity and stickiness (Jayasundera et al., 2009). Whey is a dairy ingredient mainly composed of lactose and globular proteins such as $\beta$-lactoglobulin and $\alpha$-lactalbumin, which allow it to be a solid carrier suitable to stabilize dried o/w emulsions (Písecký, 2005). According to Demetriades et al. (1997), whey proteins can help form physically stable food emulsions by forming closely packed monolayer of globular 
proteins at the interface. Moreover, Fäldt and Bergenst/aahl (1996b) demonstrated an interaction between lactose and whey proteins that prevents the emulsion droplets from coalescing during drying and redispersion.

Spray-drying is divided into three stages (Fig. 1). The liquid emulsion enters the spray-dryer chamber by its ceiling and exits at the bottom of the chamber as a powder. A proportion of the created powder is carried out by the outlet warm air because of its lightness. Then, cyclonic separation removes dry products from humid air through vortex separation, i.e. rotational effects and gravity. This is done through one or several cyclones placed outside the dryer in order to reduce powder losses in the air (Gharsallaoui et al., 2007). The powder going through the cyclones is called "fines". The final drying and cooling occurs in a fluidized bed where fines and powder from the end of the drying chamber converge.

Dried emulsions have to be easily dispersed when mixed with water. But the drying process can also cause some instability by adversely affecting the properties of the interfacial layer. The surface composition of a spray-dried dairy emulsion is primarily determined by the ingredients, pre-treatment process and spraydrying parameters (Vignolles et al., 2010). Even if the surface is generally dominated by proteins while fat is largely encapsulated within the particles, the types of protein, temperature and $\mathrm{pH}$ treatments can influence the surface composition of the powder. Those extrinsic environmental factors can actually modify the percentage of lactose, proteins and oil at the surface of spray-dried powders (Vignolles et al., 2007).

Most of the existing literature examines dairy powders with a low fat content, more particularly their surface composition. For example, Vignolles et al. (2007) reported in whole milk, that the amount of surface fat is significantly higher in the fines coming out from the second cyclone compared to powder from a spraydryer chamber. Nevertheless, the study of dried emulsions with a high fat content ( $50 \%$ or more) is a topic of interest for its industrial applications. Indeed, products with $50 \%$ of fat content or more are used in order to substitute milk or butter in food applications such as cakes, creams, sauces, or even ice cream. Those milk replacers need to be stable in liquid phase and homogeneous. At present, as explained by Martinet et al. (2005), elaboration of such emulsions is still mostly empirical and frequently based on industrial know-how.

The objective of the present study is to determine to what extend can the different stages of spray-drying affect the physicchemical characteristics and the functionality of commercial whey dried emulsions with a high fat content. This work investigates some physico-chemical properties of final products and powders collected from the spray-drying chamber, the cyclones and after the packing as well as those of the corresponding reconstituted emulsions.

Particle size, structure and free fat content of powders were determined. Reconstituted emulsions made from those powders were characterized in terms of physical stability and size distribution.

\section{Materials and methods}

\subsection{Materials}

As in the work of Kim et al. (2002, 2005, 2009), spray-dried whey emulsions were manufactured at a dairy company plant. Liquid whey from different cheese factories with a protein content of $c a .8 \mathrm{~g} \pm 1 \mathrm{~g}$ per $100 \mathrm{~g}$ of dry weight and a lactose content of ca. $70 \mathrm{~g} \pm 5 \mathrm{~g}$ per $100 \mathrm{~g}$ of dry weight was used. Palm oil was used as the dispersed phase. Palm oil, with a melting temperature between 36 and $42{ }^{\circ} \mathrm{C}$, is made up of triglycerides containing mostly two fatty acid residues: palmitic acid (44\%) and oleic acid (38\%), respectively saturated and unsaturated. Six different batches of production were studied. As in Keowmaneechai and McClements (2002) work, raw materials vary in composition between batches and values should be taken as approximates.

\subsection{Industrial process}

The powders were made in the industrial-scale as follows. Whey and palm oil were mixed together to provide a final powder-fat content of $50 \mathrm{~g} / 100 \mathrm{~g}$. Homogenization was achieved using a Manton Gaulin type atomiser (homogenization pressure: 10-20 MPa). The liquid emulsion was atomized via a rotary atomizer in a spray-drier with a capacity of at least 3 tonnes of powders per hour (Fig. 1). Palm oil was liquid during all the process. Six different batches of the same formulation were studied right after their production.

For each production, dry emulsions at different stages of manufacture were sampled: the final powder (FP), just before packing (Fig. 1); powder without fines (PWF) collected at the end of the spray-drying chamber; fines 1 (F1), which is powder from the first cyclone; fines 2 (F2), which is powder from the second cyclone and fines $1 \& 2$ (F1\&2) corresponding to a mix of fines 1 and fines 2 , when they joined on a vibrating chute before meeting the PWF in the fluidized bed.

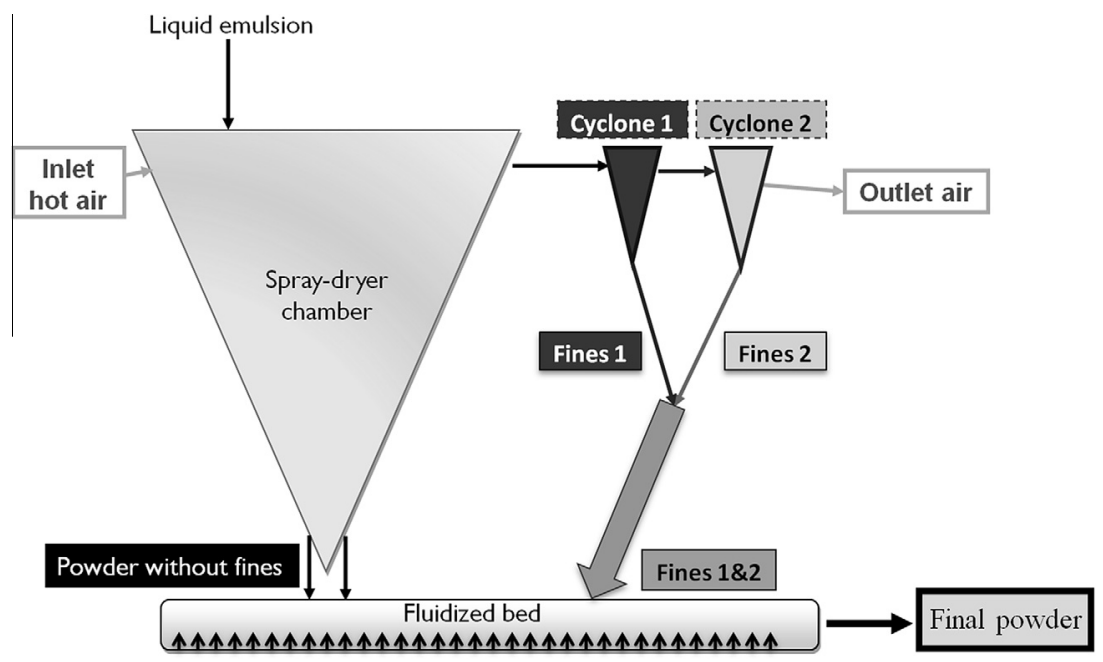

Fig. 1. Sketch of the industrial spray-drying process. 


\subsection{Methods}

\subsubsection{Characterization of powders}

2.3.1.1. Optical microscopy. A small amount of powder was placed on a glass slide and observed with an optical microscope equipped with a camera. Pictures were taken to analyze the differences in size and structure.

\subsubsection{Scanning electron microscopy (SEM). Size and morphology of} the particles were investigated by SEM (Soottitantawat et al., 2005) in partial vacuum. Powder particles were mounted on metal stubs with double-sided tape. Because of the partial vacuum. A JEOL 6301F SEM (JEOL UK Ltd., Welwyn Garden City, Herts., England) was used, at an accelerating voltage of $20 \mathrm{kV}$.

Pictures were taken to measure particle sizes with an image analysis software (imageJ, National Institutes of Health (NIH), USA). Size distribution, in number of particles, was obtained by measuring Feret's diameter as explained by Vehring (2008) on ca. 60 individual powder particles for each sample.

2.3.1.3. Free fat quantification. The free fat content was determined for each powder with a method adapted from the AFNOR-NF V04-403 Method as follows.

A volume of $150 \mathrm{ml}$ petroleum ether was added to $1 \mathrm{~g}$ of powder and the mixture was stirred for $5 \mathrm{~min}$ before being filtered. The filtrate was collected in a tarred beaker and submitted to evaporation before being weighed out. The percentage of free fat (FF) was determined using the expression:

$\mathrm{FF}=100 \times\left(m_{1}-m_{0}\right) / F$

where $m_{0}$ is the mass of the beaker, $m_{1}$ the mass of the beaker containing the sample after evaporation and $F$ the mass of fat in $1 \mathrm{~g}$ of powder, determined by the Gerber method adapted by Sørensen et al. (1978).

\subsubsection{Characterization of reconstituted emulsions}

2.3.2.1. Emulsion reconstitution. The emulsions were reconstituted as follows: $10 \mathrm{~g}$ of powder were dispersed with $100 \mathrm{ml}$ of water at $50{ }^{\circ} \mathrm{C}$ in a $250 \mathrm{ml}$ beaker, and stirred for $5 \mathrm{~s}$ at room temperature. The resulted suspensions were called "reconstituted emulsions". Additional samples were made to dissociate flocculated droplets using the following procedure (Tomas et al., 1994; Tual et al., 2006): $50 \mathrm{ml}$ of reconstituted emulsions were added with $50 \mathrm{ml}$ of aqueous SDS solution (sodium dodecyl sulfate) at $20 \mathrm{~g} / \mathrm{L}$, an ionic surfactant which displaces proteins from the interface (Demetriades and Julian McClements, 2000; van Aken, 2003). These suspensions (SDS emulsions) were stirred for $30 \mathrm{~min}$ before any measurement.

2.3.2.2. Particle size measurements. As in Millqvist-Fureby et al. (2001) and in Giteau et al. (2008), the size distribution of fat droplets and their aggregation were determined by laser light scattering using a Mastersizer 2000S (Malvern Instruments, Malvern Orsay, France). It is equipped with a He-Ne laser $(\lambda=633 \mathrm{~nm})$ and a blue light diode $(\lambda=466 \mathrm{~nm})$. The refractive index and the absorption value were respectively set to 1.450 and 0.01 for palm oil and 1.333 and 0.00 for the aqueous phase.

Measurements were made for both reconstituted emulsions and SDS emulsions. The result was the mean of two independent samplings of each reconstituted emulsion and three successive measurements each time. For SDS emulsions, each sample was measured until the value of the median diameter was stabilized, requiring 3-40 successive measurements depending on the powder samples. The variability of the mean droplet diameter made on two samples with the same composition prepared at different times was $5 \%$ for the floculated (reconstituted emulsions) and more than $10 \%$ for the non-floculated emulsions (SDS emulsions).

The results were recorded as size distribution in the absence or presence of SDS.

2.3.2.3. Optical microscopy. Reconstituted emulsions were diluted by 1 in 2 with distilled water. Then a droplet was placed between a glass slide and a slip cover, and observed with an optical microscope equipped with a camera. Pictures were taken to analyze the differences in size and structure.

2.3.2.4. Stability index of reconstituted emulsions. The reconstituted emulsion made from $10 \mathrm{~g}$ of powder and $100 \mathrm{ml}$ of water was left aside for $20 \mathrm{~min}$ at room temperature. Then, $50 \mathrm{ml}$ were pipetted out from the bottom of the beaker corresponding to the lower phase, and with the rest of the emulsion known as the upper phase. Total fat content was measured (Gerber method) in each phase. A stability index (SI) was calculated as a percentage of the total fat content ratio between those two phases, as follows:

$\mathrm{SI}=100 \times$ fat content in the lower phase/fat content in the upper phase

The variability of the measurement made on two samples with the same composition prepared at different times was less than $8 \%$. A high index $(>80 \%)$ means almost no phase separation due to creaming. A lower index (<80\%), indicates some phase separation has occurred. The lower the index, the higher the creaming.

Unlike the measurement of creaming via a Turbiscan MA 2000 (Ramonville St Agne, France) which gives a qualitative indication of the oil droplets distribution (Blijdenstein et al., 2003), this method allows us to quantify the phase separation after $20 \mathrm{~min}$. The stirring time and the timeout before the measurement were chosen because of industrial uses. Indeed, the emulsions need to be stable, i.e. homogeneous, with a minimum mixing time of $20 \mathrm{~min}$ in order to be used as ingredients in food products.

\subsubsection{Statistics}

Analysis of variance (ANOVA) was carried out using XLSTAT 2012. Tukey's $t$-test was used for pair comparisons with a level of significance determined at $P<0.001$.

\section{Results and discussion}

\subsection{Characterization of powders collected from different stages of spray-drying}

\subsubsection{Light and scanning electron microscopy}

Each kind of samples were collected and analyzed by both optical and scanning electron microscopy (Fig. 2a). Images from optical microscopy (Fig. 2A-D) show black spheres corresponding to spherical particles of powder. According to Nandiyanto and Okuyama (2011), the maximum structural stability of a solution is in a spherical form, indicating that this process is suitable for the production of dried whey emulsions. SEM micrographs (Fig. 2E-H) show smooth and round particles, without dents appearing on the surface consistent to the study of Nijdam and Langrish (2006) on high lactose content and low protein content $(<20 \%$ DM). Moreover particles to particles interactions are visible on micrographs. This is attributed to both high surface fat coverage (Nijdam and Langrish, 2006; Shrestha et al., 2007) which creates an hydrophobic surface and therefore poor rehydration and flowability properties (Vignolles et al., 2009) and the stickiness of sugar protein solution, though it is partly overcome by the protein migration at the air-water interface (Adhikari et al., 2009a,b). This is in agreement with the results on surface fat of dairy powders (fat content $40 \%$ of DM), detailed by Vignolles et al. (2009). 
a. Micrographs
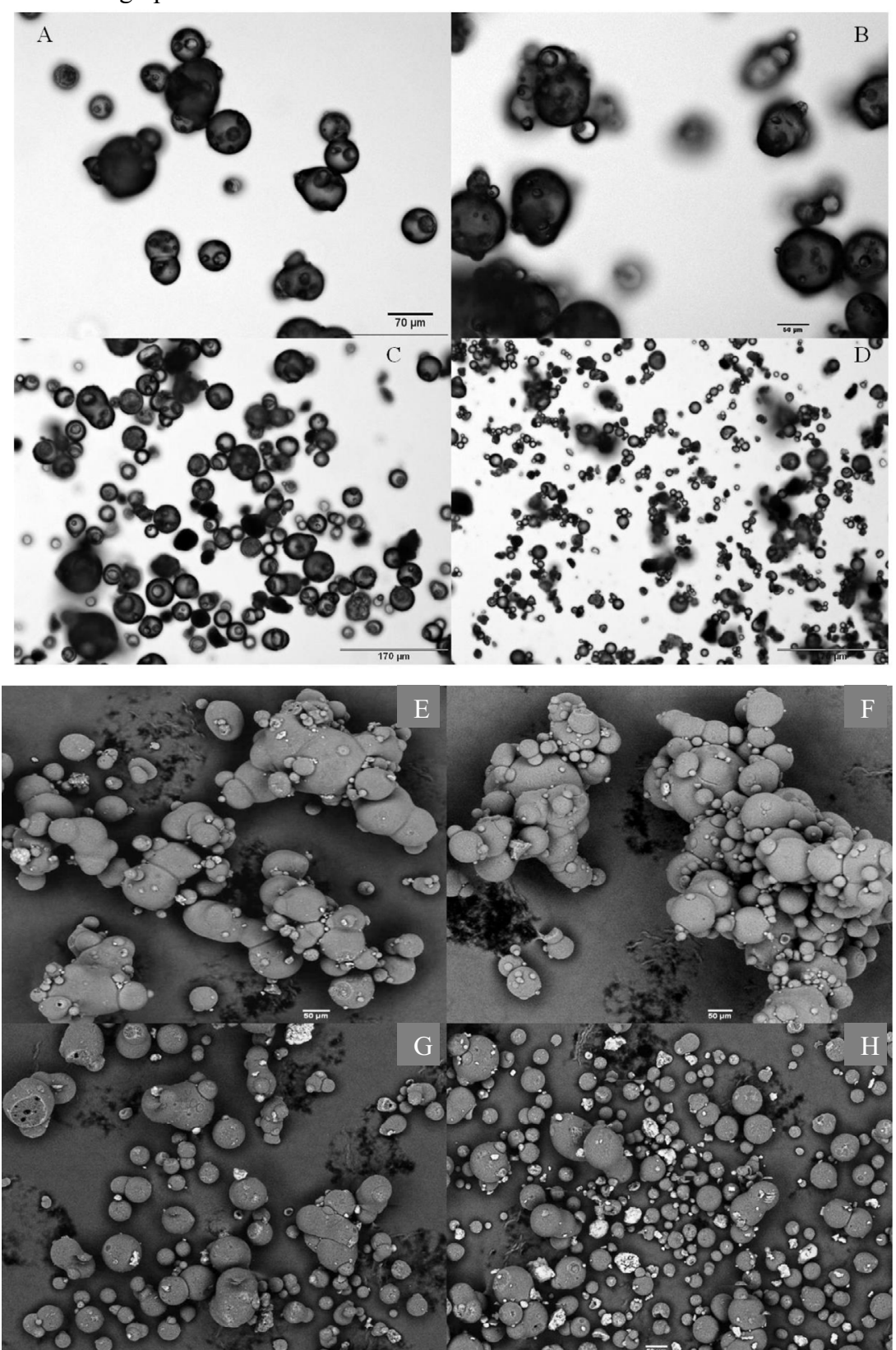

b. Size distribution

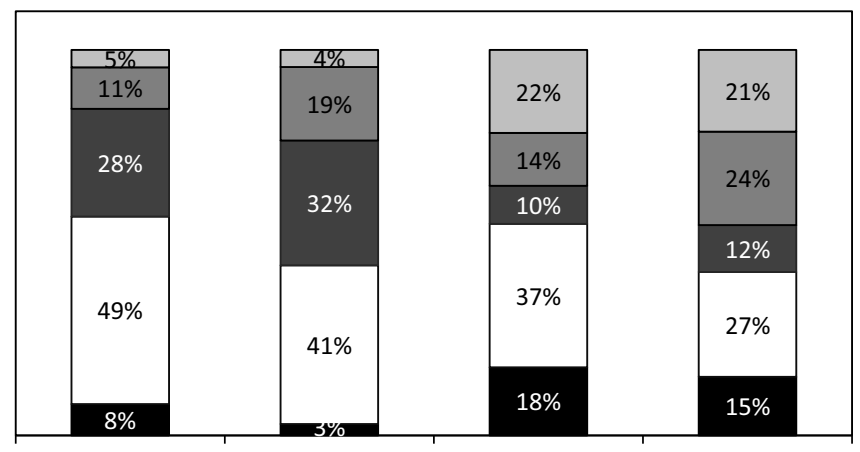

F1\&2

F1

PWF

FP

$\square<20 \mu \mathrm{m} \quad \square 20-40 \mu \mathrm{m} \quad \square 40-60 \mu \mathrm{m} \quad \square 60-80 \mu \mathrm{m} \quad \square 80-110 \mu \mathrm{m}$

Fig. 2. Characterization of powders at different stages of spray-drying. (a) Light micrographs (A-D) and scanning electron micrographs (E-H) of different types of spray-dried whey emulsions: final powder ( $A$ and $E$ ); powder without fines (B and F); fines 1 ( $C$ and $G$ ); fines 2 (D) fines $1 \& 2(\mathrm{H})$. (b) Size distribution of powder particles determined from scanning electron micrographs. Figures refer to relative percentage in number for each class of size. 
Fig. 2b depicts results of size particle determination obtained by image analysis. For all kinds of sample, the $20-40 \mu \mathrm{m}$ class is the most abundant (27\% in FP; $49 \%$ in F1\&2), and the larger particles have a diameter of $105 \mu \mathrm{m}$. In Gharsallaoui et al. (2007) study, powders that range from 10 to $50 \mu \mathrm{m}$ are defined as "very fine" and 2-3 $\mathrm{mm}$ are defined as "large". In Sharma et al. (2012) review, powders are called fines particles if their size is lower than $90 \mu \mathrm{m}$. Therefore, our dried emulsions can be labeled as "fine powders".

Size distributions of PWF and FP are similar. This is particularly true for three size classes, i.e. less than $20 \mu \mathrm{m}$ (18\% for PWF; $15 \%$ for FP), $40-60 \mu \mathrm{m}$ (10\% for PWF, $12 \%$ for FP) and $80-110 \mu \mathrm{m}$ (22\% for PWF, $21 \%$ for FP). For fines, $23 \%$ of particles or less have a diameter higher than $60 \mu \mathrm{m}$ (Fig. 2b). This percentage is much higher for PWF (36\%) and FP (45\%). Comparing distribution of fines 1 and fines 182 indicates that the presence of fines 2 lowers the average diameter. In fact, the percentage of particles smaller than $40 \mu \mathrm{m}$ is $44 \%$ in fines 1 and $56 \%$ in fines $1 \& 2$. This agrees with light microscopy observations showing that fines 2 are roughly twice as small as fines 1 (Fig. 2a G and $\mathrm{H}$ ).

Concerning F1 and F2, optical microscopy (Fig. 2C and D) shows, in addition to black spheres, small light spheres encircled by a black layer (becoming white and shiny under polarized light), the latter representing fat droplets, with an average diameter of $15 \mu \mathrm{m}$. This means that more fat droplets are present in the powders that are processed by the cyclones. Since small size or low density particles are driven through the cyclones, two hypotheses can be suggested. (i) Since the fat droplets are even smaller and lighter than the composites, therefore they have higher tendency to go through the cyclones; (ii) or, fat droplets can be released from the surface of powder particles by undergoing mechanical stress in the cyclones. The first hypothesis is unlikely since the fat content of PWF and F1\&2 is similar (data not shown). The second hypothesis agrees with the work after Vignolles et al. (2007) which showed higher surface fat coverage on fines than on final powder.

\subsubsection{Free fat quantification}

As part of the investigation of the effect of cyclones on powder quality, free fat quantification was performed on each sample (Table 1). Free fat is defined as the fraction of fat that is extractable by organic solvent (Kim et al., 2005) and assimilated to non-encapsulated fat present in a dry emulsion. A high free fat content is one of the reasons that can explain poor rehydration and flowability properties in dairy powders (Vignolles et al., 2009). Therefore it is crucial to determine which stage of spray-drying generates free fat.

The percentage of free fat (\%FF) is ca. $8 \pm 3 \%$ in $\mathrm{FP} ; 3 \pm 1.5 \%$ in PWF and $20 \%$ or more in fines. Moreover, the free fat content is significantly higher in fines $2(37 \pm 10 \%)$ than in fines $1(20 \pm 3.5 \%)$. It is worthy of note that this high free fat content can be linked to the large presence of fat droplets observed in fines by microscopy. Again, as mentioned above (Section 3.1.1.) either fat droplets go primarily through the cyclones, or are released from powder particles due to mechanical stress. This is consistent with results reported by Vignolles et al. (2007) that the amount of surface fat is increased when cyclones are used to separate the dry product from the drying air.

\section{Table 1}

free fat content $(\mathrm{g} / 100 \mathrm{~g})$ in the five kinds of powders: Final powder (FP); powder without fines (PWF); fines 1 (F1); fines 2 (F2); fines 1\&2 (F1\&2).

\begin{tabular}{lrl}
\hline Powders & \multicolumn{1}{c}{ \%FF } & Statistical test \\
\hline FP & $7.8 \pm 2.7$ & A \\
PWF & $3.1 \pm 1.5$ & A \\
F1\&2 & $19.6 \pm 6.9$ & B \\
F1 & $20.5 \pm 3.5$ & B \\
F2 & $37 \pm 9.9$ & C
\end{tabular}

Values are shown as mean \pm SD of six samples analyzed in duplicates.
Since the \%FF is significantly different in F1, F2 and PWF, their relative proportion in the FP can be inferred by measuring the free fat content in a powder. In our samples, a direct link between composition in terms of powders and \%FF was obtained (results not provided). Consequently, from the value of free fat contents, percentage of fines in the FP was estimated to be ca. 20-30\%. In the same way, since \%FF is much higher in $\mathrm{F} 2(\mathrm{FF}=37 \pm 10 \%)$ than in fines 1 ( $F F=20 \pm 3.5 \%)$, it is inferred that $F 1$ make up for a large portion of $\mathrm{F} 1 \& 2$ ( $\mathrm{FF}=19.6 \pm 6.9 \%)$.

\subsection{Characterization of reconstituted emulsions}

Most spray-dried powders are not used as such but need to be either incorporated in a food matrix or be rehydrated for final use and is why structure and stability characterization of reconstituted emulsions is of great interest.

\subsubsection{Particle size distribution}

Laser light scattering is known as a relevant method to characterize fat droplets size and instability (Kulmyrzaev and Schubert, 2004; Pongsawatmanit et al., 2006; Tual et al., 2006).

3.2.1.1. Aggregation. The reconstituted emulsion made with PWF has droplets with a diameter range from $0.2-15 \mu \mathrm{m}$ (Fig. $3 \mathrm{~A})$. Indeed, the size distribution is monomodal $\left(d_{v(0,5)} \approx 0.6 \mu \mathrm{m}\right)$. This is typical of a fine dairy emulsion (Tomas et al., 1994). In the presence of SDS (SDS emulsions), the distribution is similar but with a higher population of particles at $0.6 \mu \mathrm{m}$ and less between 1.5 and $15 \mu \mathrm{m}$. For example, in reconstituted emulsion, $90 \%$ of the oil volume is made of droplets lower than $3 \mu \mathrm{m}$. This value goes down to $1.5 \mu \mathrm{m}$ in SDS emulsion. This demonstrates that, in those products, particles greater than $1.5 \mu \mathrm{m}$ represent aggregates, even though aggregation is quite low.

Reconstituted emulsions from fines 1 , fines 2 and fines $1 \& 2$ (Fig. 3C) have the same first peak, but also have a peak around $80 \mu \mathrm{m}$. This second peak diminishes in the presence of SDS indicating disruption of oil droplet aggregates (Fig. 3B).

Thanks to size distributions, an aggregation index (Ia) corresponding to the volume of oil droplet aggregates, in per cent was calculated (Fig. 3D) using the expression:

$I a=\sum_{i=x}^{n} \theta$ without SDS $-\sum_{i=x}^{n} \theta$ with SDS

where $\theta$ is the percentage of volume particles in class $i, n$ is the higher class of particle size and $x$ the class of particle size where: $\theta_{\text {with SDS }} \leqslant \theta_{\text {without SDS. }}$

This aggregation index (Fig. 3D) is around $13 \pm 4 \%$ for each powder. This confirms, as observed above, that aggregation is minor and not significantly different from one product to another.

3.2.1.2. Coalescence. In the presence of SDS, while PWF shows a mono-modal distribution (Fig. 4A), all the other products contain a part of larger particles (greater than $10 \mu \mathrm{m}$ ). This means that in addition to oil droplet aggregates, those reconstituted emulsions do contain large oil droplets. The latter are due to coalescence since no such large droplets were observed in powder particles (Fig. 2a).

From size distribution in the presence of SDS, a coalescence index (IC) corresponding to the volume of oil in coalesced droplets (Fig. 4B) was calculated, in per cent, using the expression:

Ic $=\sum_{i=y}^{n} \theta$ with SDS

where $\theta$ is the percentage of volume particles in class $i, n$ is the higher class of particle size and $y$ the class of particle sizes where: $\theta$ with $\operatorname{SDS}(y) \geqslant \theta$ with SDS $(y-1)$. 

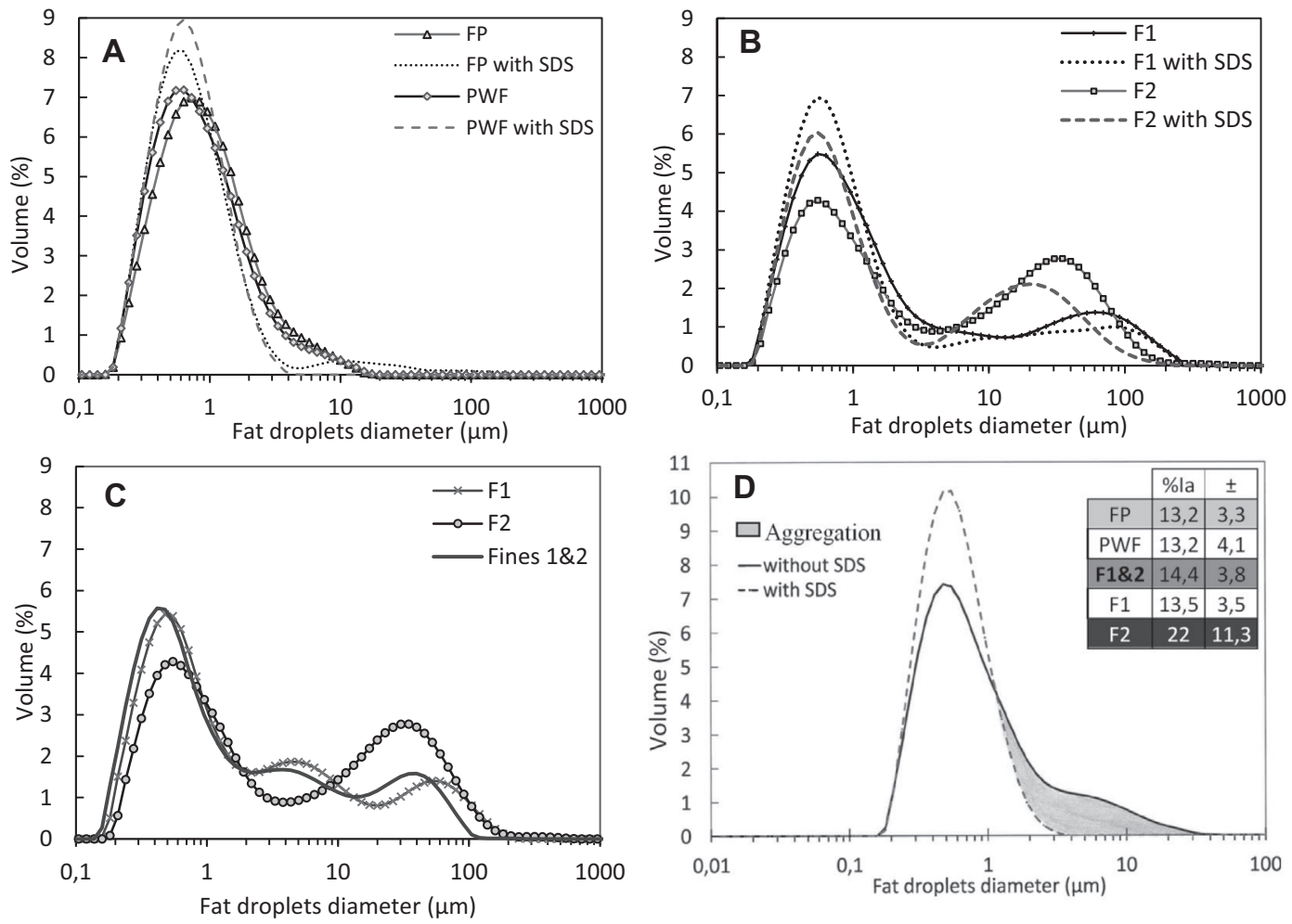

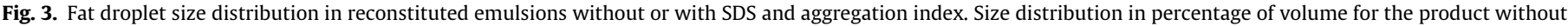

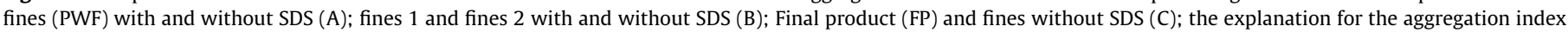
and its values (D).
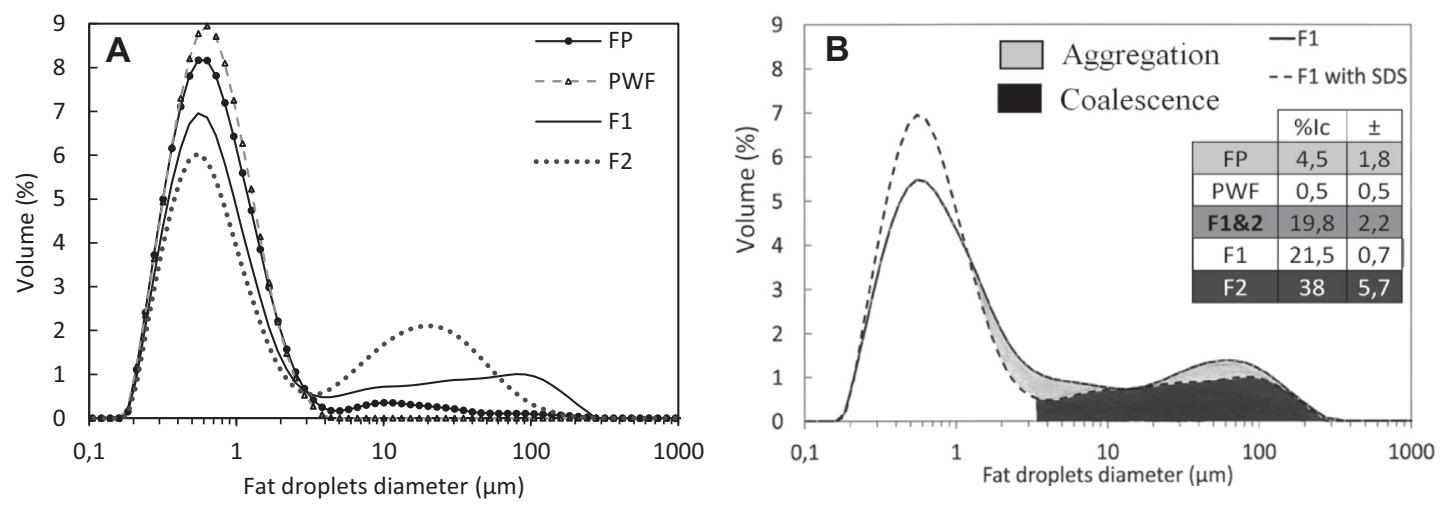

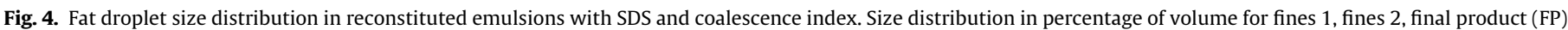
and the product without fines (PWF) with SDS (A); the explanation for the coalescence index and its values (B).

This index of coalescence is $4.5 \pm 1.8 \%$ in FP. PWF exhibits almost no coalescence (Ic $<1 \%)$, whereas in fines 1 , the coalescence index is ca. $20 \%$ and higher than $35 \%$ in fines 2 (Fig. 4B). According to those results, the higher the numbers of cyclones (none for PWF; one for fines 1 and two for fines 2 ), the more powder present the higher the tendency for coalescence when reconstituted in water. This agrees with data obtained for free fat quantification. Indeed, the greater the free fat content, the larger the second peak (diameter $\sim 80 \mu \mathrm{m}$ ) in size distribution, and the greater the coalescence. Free fat tends to coalesce. Due to their hydrophobic nature, nonencapsulated fat droplets tend to merge with one another in aqueous mediums such as reconstituted emulsions.

From these measurements and without knowing the proportion of each powder in the final product, the proportion of F1 and F2 in F1\&2 can be inferred. Indeed, because the Ic is significantly similar for F1 and F1\&2 but significantly different from that of F2, it can be determined that there are more fines 1 than fines 2 in fines $1 \& 2$. This supports the results seen in free fat quantification where FP is mainly made of PWF and F1\&2 of fines 1 (Section 3.1.2.). Additionally, the physico-chemical features of the final powder are similar to those of a mixture of PWF and F1\&2 in the same relative proportions as in the FP. This suggests that the fluidized bed does not significantly affect the powder characteristics.

\subsubsection{Light microscopy}

Micrographs of reconstituted emulsions allow us to visualize the fat droplets (Fig. 5). Large fat droplets are present in fines 1 and in fines 2, indicating coalescence. The droplets are even larger in fines 2 than in fines 1 . At a lower level, large droplets are also visible on the FP. On the contrary, the fat droplets from the 


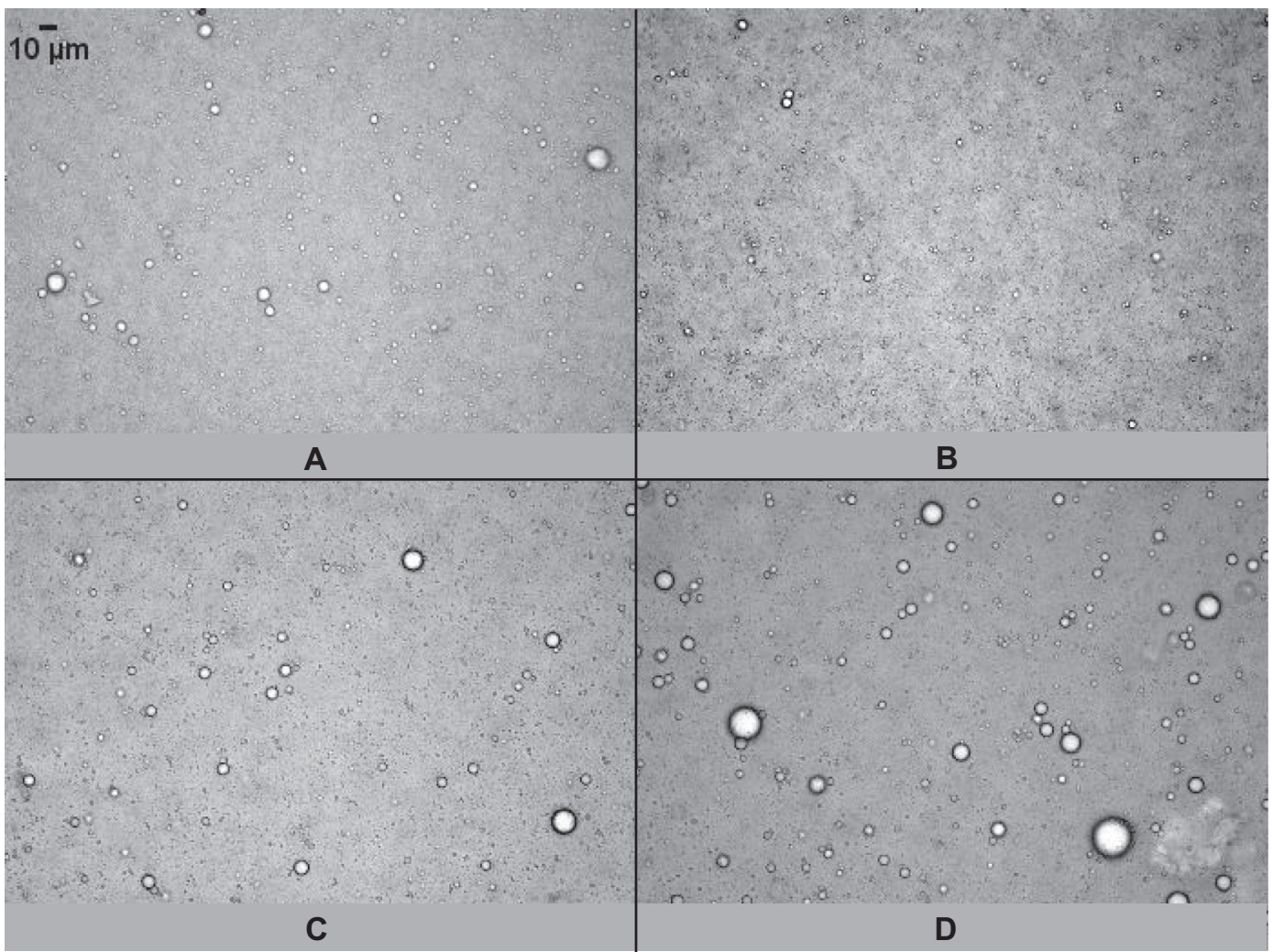

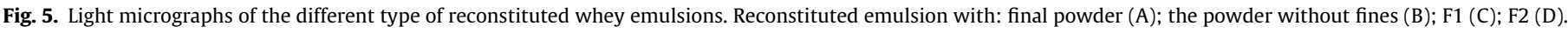

reconstituted emulsion made with PWF are small; less than $10 \mu \mathrm{m}$. This is coherent with particle size distribution results on coalescence.

\subsubsection{Stability}

For many emulsions like infant milks or beverages, the stability of reconstituted emulsions is a crucial factor with regards to food applications; no phase separation should occur after reconstitution and prior to use.

As shown in Table 2, final products selected for the present study exhibit a high stability index (SI $\geqslant 95 \%)$. Reconstituted emulsions from powders collected at the different process stages do not differ in terms of stability index ( $\mathrm{SI} \geqslant 80 \%$ ) except for the reconstituted emulsions made with F2. Indeed, SI for fines 2 ( $\mathrm{SI}=65 \pm 19 \%$ ) is lower than that of the other reconstituted emulsions. This poor stability can be explained by the results of free fat content and coalescence index reported above. Indeed, a high free fat content ( $\mathrm{FF}=37 \pm 10 \%$ ) means that fat droplets do not have a sufficient protein coverage, which makes them prone to coalescence (Ic $=38 \pm 5.7 \%$ ) after reconstitution. Yet, this lack of stability of emulsions reconstituted from fines 2 does not affect the index

Table 2

stability index (SI) of reconstituted emulsions: Final powder (FP); powder without fines (PWF); fines 1 (F1); fines 2 (F2); fines 1 \& 2 (F1 \& 2).

\begin{tabular}{lll}
\hline Powders & \%SI & Statistacal test \\
\hline FP & $97.3 \pm 1.1$ & A \\
PWF & $95.3 \pm 2.4$ & A \\
F1\&2 & $89.2 \pm 5.5$ & A \\
F1 & $90.0 \pm 2.8$ & A \\
F2 & $65.5 \pm 19.1$ & B
\end{tabular}

Values are shown as mean \pm SD of six samples analyzed in duplicates. stability of reconstituted emulsions from the final powders. They namely represent a low fraction in the FP.

\section{Conclusion}

Food industrial powders with a very high fat content $(50 \mathrm{~g} /$ $100 \mathrm{~g}$ ), collected at various stages of the spray-drying process, as well as emulsions resulting from their reconstitution in water, were characterized. Powders are made of spherical particles (mostly ca. 20-40 $\mu \mathrm{m}$ ); fat droplets are mainly present in the powders processed by the cyclones, i.e. in fines.

Reconstitution of most powders in water gives stable (SI >95\%) and fine emulsions $\left(d_{v(0,5)} \approx 0.6 \mu \mathrm{m}\right)$ with a low aggregation index (ca. 13\%) and almost no coalescence. However, some coalescence occurs in reconstituted emulsions from fines (Ic ca. $20 \%$ for $\mathrm{F} 1$ and $40 \%$ for F2), which is likely to correlate to their free fat content (ca. 20\% in F1\&2 and higher than 35\% in F2). Moreover reconstituted emulsions from fines 2 are less stable (SI ca. 65\%) than the other. It can be concluded that a high free fat content in powders induces coalescence upon reconstitution in water; which lead to quick destabilization. Further investigation should be done considering the impact of the formulation, especially the protein type, on the free fat content in fines. Nevertheless, in the final product studied here, the amount of fines is too low to have a direct effect on the quality of the final reconstituted emulsion. This is especially true for fines 2 which have the lowest stability.

In future study, it would be relevant to investigate the structure of emulsion prior to spray drying in order to compare it to with what of its reconstituted emulsion.

The new instability indexes generated in this article, based on fat droplet distribution of reconstituted emulsions, could be applied on any kind of liquid emulsions that undergo aggregation and/or coalescence. 
To conclude, the results of this work show that structure and properties of powders and reconstituted emulsions are affected by the processing stages of spray-drying.

\section{Acknowledgements}

The authors acknowledge the French National Organization for Research and Technology (ANRT) for their financial support through a research grant for Emma Donz. Rebecca Wong is thanked for linguistic revision.

\section{References}

Adhikari, B., Howes, T., Bhandari, B.R., Langrish, T.A.G., 2009a. Effect of addition of proteins on the production of amorphous sucrose powder through spray drying. Journal of Food Engineering 94 (2), 144-153. http://dx.doi.org/10.1016 j.jfoodeng.2009.01.029.

Adhikari, B., Howes, T., Wood, B.J., Bhandari, B.R., 2009b. The effect of low molecular weight surfactants and proteins on surface stickiness of sucrose during powder formation through spray drying. Journal of Food Engineering 94 (2), 135-143. http://dx.doi.org/10.1016/j.jfoodeng.2009.01.022.

Blijdenstein, T.B.J., van Vliet, T., van der Linden, E., Van Aken, G.A., 2003. Suppression of depletion flocculation in oil-in-water emulsions: a kinetic effect of $\beta$-lactoglobulin. Food Hydrocolloids 17 (5), 661-669.

Christensen, K.L., Pedersen, G.P., Kristensen, H.G., 2001a. Preparation of redispersible dry emulsions by spray drying.pdf. International Journal of Pharmaceutics 212, 187-194.

Christensen, K.L., Pedersen, G.P., Kristensen, H.G., 2001b. Technical optimisation of redispersible dry emulsions. International Journal of Pharmaceutics 212 (2), 195-202.

Demetriades, K., Julian McClements, D., 2000. Influence of sodium dodecyl sulfate on the physicochemical properties of whey protein-stabilized emulsions. Colloids and Surfaces A: Physicochemical and Engineering Aspects 161 (3) 391-400.

Demetriades, K., Coupland, J.N., McClements, D.J., 1997. Physical properties of whey protein stabilized emulsions as related to $\mathrm{pH}$ and $\mathrm{NaCl}$. Journal of Food Science 62 (2), 342-347.

Dickinson, E., 2010. Food emulsions and foams: Stabilization by particles. Current Opinion in Colloid and Interface Science 15 (1-2), 40-49. http://dx.doi.org/ 10.1016/j.cocis.2009.11.001.

Fäldt, P., Bergenst/aahl, B., 1996a. Spray-dried whey protein/lactose/soybean oil emulsions. 1. Surface composition and particle structure. Food Hydrocolloids 10 (4), 421-429.

Fäldt, P., Bergenst/aahl, B. ( 1996b. Spray-dried whey protein/lactose/soybean oil emulsions. 2. Redispersability, wettability and particle structure. Food Hydrocolloids 10 (4), 431-439.

Gharsallaoui, A., Roudaut, G., Chambin, O., Voilley, A., Saurel, R., 2007. Application of spray-drying in microencapsulation of food ingredients: an overview. Food Research International 40 (9), 1107-1121. http://dx.doi.org/10.1016/ j.foodres.2007.07.004.

Giteau, A., Venierjulienne, M., Marchal, S., Courthaudon, J., Sergent, M. Monteromenei, C., Benoit, J., 2008. Reversible protein precipitation to ensure stability during encapsulation within PLGA microspheres. European Journal of Pharmaceutics and Biopharmaceutics 70 (1), 127-136. http://dx.doi.org/ 10.1016/j.ejpb.2008.03.006.

Hayati, I.N., Che Man, Y.B., Tan, C.P., Aini, I.N., 2007. Stability and rheology of concentrated O/W emulsions based on soybean oil/palm kernel olein blends Food Research International 40 (8), 1051-1061.

Jayasundera, M., Adhikari, B., Aldred, P., Ghandi, A., 2009. Surface modification of spray dried food and emulsion powders with surface-active proteins: a review. Journal of Food Engineering 93 (3), 266-277.

Keowmaneechai, E., McClements, D.J., 2002. Effect of $\mathrm{CaCl} 2$ and $\mathrm{KCl}$ on physiochemical properties of model nutritional beverages based on whey protein stabilized oil-in-water emulsions. Journal of Food Science 67 (2), 665671.

Kim, E.H.-J., Chen, X.D., Pearce, D., 2002. Surface characterization of four industrial spray-dried dairy powders in relation to chemical composition, structure and wetting property. Colloids and Surfaces B: Biointerfaces 26 (3), 197-212.

Kim, E.H.-J., Chen, X.D., Pearce, D., 2005. Melting characteristics of fat present on the surface of industrial spray-dried dairy powders. Colloids and Surfaces B: Biointerfaces 42 (1), 1-8.
Kim, E.H.-J., Chen, X.D., Pearce, D., 2009. Surface composition of industrial spraydried milk powders. 2. Effects of spray drying conditions on the surface composition. Journal of Food Engineering 94 (2), 169-181.

Kulmyrzaev, A.A., Schubert, H., 2004. Influence of $\mathrm{KCl}$ on the physicochemical properties of whey protein stabilized emulsions. Food Hydrocolloids 18 (1), 1319. http://dx.doi.org/10.1016/S0268-005X(03)00037-7.

Lizarraga, M.S., Pan, L.G., Añon, M.C., Santiago, L.G., 2008. Stability of concentrated emulsions measured by optical and rheological methods. Effect of processing conditions-I. Whey protein concentrate. Food Hydrocolloids 22 (5), 868-878. http://dx.doi.org/10.1016/j.foodhyd.2007.04.012.

Martinet, V., Valentini, C., Casalinho, J., Schorsch, C., Vaslin, S., Courthaudon, J.L., 2005. Composition of interfacial layers in complex food emulsions before and after aeration: effect of egg to milk protein ratio. Journal of Dairy Science 88 (1), 30-39.

Millqvist-Fureby, A., Elofsson, U., Bergenst/aahl, B., 2001. Surface composition of spray-dried milk protein-stabilised emulsions in relation to pre-heat treatment of proteins. Colloids and surfaces B: Biointerfaces 21 (1), 47-58.

Nandiyanto, A.B.D., Okuyama, K., 2011. Progress in developing spray-drying methods for the production of controlled morphology particles: from the nanometer to submicrometer size ranges. Advanced Powder Technology 22 (1), 1-19. http://dx.doi.org/10.1016/j.apt.2010.09.011.

Nijdam, J.J., Langrish, T.A.G., 2006. The effect of surface composition on the functional properties of milk powders. Journal of Food Engineering 77 (4), 919925

Písecký, J., 2005. Spray drying in the cheese industry. International Dairy Journal 15 (6-9), 531-536. http://dx.doi.org/10.1016/j.idairyj.2004.11.010.

Pongsawatmanit, R., Harnsilawat, T., McClements, D.J., 2006. Influence of alginate, $\mathrm{pH}$ and ultrasound treatment on palm oil-in-water emulsions stabilized by $\beta$-lactoglobulin. Colloids and Surfaces A: Physicochemical and Engineering Aspects 287 (1-3), 59-67. http://dx.doi.org/10.1016/j.colsurfa.2006.03.022.

Rattes, A.L.R., Oliveira, W.P., 2007. Spray drying conditions and encapsulating composition effects on formation and properties of sodium diclofenac microparticles. Powder Technology 171 (1), 7-14. http://dx.doi.org/10.1016/ j.powtec.2006.09.007.

Schuck, P., 2002. Spray drying of dairy products: state of the art. Le Lait 82 (4), 375382. http://dx.doi.org/10.1051/lait:2002017.

Sharma, A., Jana, A.H., Chavan, R.S., 2012. Functionality of milk powders and milkbased powders for end use applications - a review. Comprehensive Reviews in Food Science and Food Safety 11 (5), 518-528. http://dx.doi.org/10.1111/ j.1541-4337.2012.00199.x.

Shrestha, A., Howes, T., Adhikari, B., Wood, B., Bhandari, B., 2007. Effect of protein concentration on the surface composition, water sorption and glass transition temperature of spray-dried skim milk powders. Food Chemistry 104 (4), 14361444. http://dx.doi.org/10.1016/j.foodchem.2007.02.015.

Soottitantawat, A., Bigeard, F., Yoshii, H., Furuta, T., Ohkawara, M., Linko, P., 2005. Influence of emulsion and powder size on the stability of encapsulated dlimonene by spray drying. Innovative Food Science and Emerging Technologies 6 (1), 107-114. http://dx.doi.org/10.1016/j.ifset.2004.09.003.

Sørensen, L H., J. Krag,1. Pisecky, Westergaard, V., 1978. Méthodes d'analyses des produits laitiers déshydratés, 4tli éd. Niro A/S. Soeborg, Denmark.

Tomas, A., Paquet, D., Courthaudon, J.-L., Lorient, D., 1994. Effect of fat and protein contents on droplet size and surface protein coverage in dairy emulsions. Journal of Dairy Science 77 (2), 413-417.

Tual, A., Bourles, E., Barey, P., Houdoux, A., Desprairies, M., Courthaudon, J--L., 2006 Effect of surfactant sucrose ester on physical properties of dairy whipped emulsions in relation to those of $\mathrm{O} / \mathrm{W}$ interfacial layers. Journal of Colloid and Interface Science 295 (2), 495-503. http://dx.doi.org/10.1016/j.jcis.2005.09.010.

Van Aken, G.A., 2003. Competitive adsorption of protein and surfactants in highly concentrated emulsions: effect on coalescence mechanisms. Colloids and Surfaces A: Physicochemical and Engineering Aspects 213 (2), 209-219.

Vehring, R. (2008). Pharmaceutical particle engineering via spray drying, 25(5). <http://www.ordonearresearchlibrary.org/Data/pdfs/IJDFR22.pdf>.

Vignolles, M.-L., Jeantet, R., Lopez, C., Schuck, P., 2007. Free fat, surface fat and dairy powders: interactions between process and product. A review. Le Lait 87 (3), 187-236. http://dx.doi.org/10.1051/lait:2007010.

Vignolles, M.-L., Lopez, C., Madec, M.N., Ehrhardt, J.J., Méjean, S., Schuck, P., Jeantet, R., 2009. Fat properties during homogenization, spray-drying, and storage affect the physical properties of dairy powders. Journal of Dairy Science 92 (1), 58-70. http://dx.doi.org/10.3168/jds.2008-1387.

Vignolles, M.-L., Lopez, C., Le Floch-Fouéré, C., Ehrhardt, J.-J., Méjean, S., Jeantet, R., Schuck, P., 2010. Fat supramolecular structure in fat-filled dairy powders: a tool to adjust spray-drying temperatures. Dairy Science and Technology 90 (2-3), 287-300. http://dx.doi.org/10.1051/dst/2009057. 